УДК 316.012:177.3

DOI 10.35423/2078-8142.2020.1.2.03

А. О. Макарова,

кандидат філософських наук, докторантка кафедри філософії та політологї Житомирського державного університету імені Івана Франка м. Житомир, Украӥна e-mail:Makarova_AO@ukr.net ORCID: https://orcid.org/0000-0001-7270-0135

\title{
ФЕНОМЕН АРХЕТИПУ У СУЧАСНИХ УКРАЇНСЫКИХ СОЦІАЛЬНО-ФІЛОСОФСЬКИХ РЕЦЕПЦІЯХ
}

Сучасна українська філософська наука перебуває у пошуку нових шляхів обтрунтування власних смислів $і$ завдань у контексті реалій та перспектив складного соиіального світу. У статті аргументується наявність соиіально-філософських рецепцій у сучасних украӥнських філософських дослідженнях феномена архетипу як методологічного інструменту вирішення иих завдань. Мета дослідження полягає у доведенні актуальності та перспективності звернення у сучасному українському сочіально-філософському дискурсі до феномена архетипу як такого, щио містить рецепиії иьього дискурсу, його теоретико-методологічних та практичних засад. Завданнями роботи є аналіз актуального стану сучасного українського соиіально-філософського дослідження архетипу; обгрунтування наявності рецепиій соиіально-філософського дискурсу у різноспеціалізованих сучасних украӥнських філософських дослідженнях з огляду на міждисииплінарність проблематики та метаграничість архетипу; окреслення перспектив використання архетипного підходу як частини методологічного дискурсу в украӥнських соціально-філософських рецепиіях майбутнього. Реалізація ичих завдань становить новизну дослідження, яке має оглядовоаналітичний характер. Архетипно-ціннісний підхід визначається як такий, що є перспективним у процесі пошуку нових підходів у сочіально-філософському дискурсі в контексті вирімення актуальних завдань філософії.

(C) Макарова А. О., 2020 
Ключові слова: архетип, сучасна украӥнська філософія, соиіально-філософські рецепиії, соціально-філософський дискурс, архетипний підхід.

У сучасній українській філософії, яка являє собою духовну традицію багатьох поколінь, також традиційно піднімаються проблеми духовного розвитку особистості у складному світі соціальних феноменів. В останнє десятиліття цей світ змінився і ускладнився ще більше. Актуальне завдання філософії, в тому числі української, все ще полягає «в осмисленні потенцій тієї чи іншої соціальної системи й людини у цій системі: 1. Аналіз параметрів наявного (реального) буття тієї чи іншої соціальної системи і людини в цій системі, а також осмислення їх потенцій. 2. Побудова проекту метаграничного (позамежного) буття соціальної системи, який принципово виходить за межі наявного, але відображає його потенції і при цьому є гуманістичним - гідна самореалізація людини в цьому проекті є метою, а не засобом. 3. Оформлення цілісної стратегії досягнення проекту метаграничного (позамежного) буття соціальної системи і людини в ній через перехід потенціального у актуальне, можливого у дійсне, що передбачає граничне буття цієї системи» (Н. Хамітов) [22, с. 21], і це не може не радувати. Адже філософію можна «зробити служницею» не лише теології, а й політики, економіки, ідеології, зв'язки яких з етикою вітчизняна філософія обговорює давно і плідно. Підсилити гуманістичну і гуманітарну традицію і окреслити в ній нову тенденцію, на нашу думку, можна через звернення соціальної філософії до аналізу феномена «архетипу» як потужного власне метаграничного ментального утворення, що несе «чисті» первинні смисли людської сутності, дає можливість до неї «повернутися», якщо не в часі та просторі, то у відчутті та осмисленні. Характеристики архетипу як енергоінформаційного (а не лише енерго- чи інформаційного) феномена та його ознаки «інваріантності», «амбівалентності», «стійкості» уможливлюють звернення до його аналізу як ретранслятора духовних смислів єдності суспільства, соціуму, держави, нації, інституцій, соціальних акторів, зокрема особистостей, у цілому. В умовах трансформативності суспільств архетипний підхід набуває значення додаткового методологічного інструменту дослідження соціа- 
льних явищ і процесів, сповнюючись рецепціями актуальних соціально-філософських смислів.

Архетипно-орієнтовані дослідження переживають в останні двадцять років «сплеск» дослідницького інтересу в сучасній Україні саме як інструмент наукового аналізу феноменів колективного несвідомого у соціокультурних (О. Кожем'якіна [9]) та ментальнонаціональних вимірах (див.: О. Гапеєва, В. Кисіль «Українська національна ідея: бібліографічний огляд сучасних поглядів...» [3]). Це тим більше свідчить про державотворчий потенціал такого аналізу, що спочатку дана тема набувала переважно психологічних рецепцій (див.: В. Менжулін «Пригоди архетипів...» [15]). «У самому базовому змісті буття української нації існують різні компоненти, смисли, цінності, архетипи, системна єдність яких поки що не знайшла цілісного наукового осмислення. Це виводить дану проблематику як соціально-значущу і актуальну», - зазначає Хоанг Тхи Кук у дисертації на здобуття вченого ступеня кандидата філософських наук за спеціальністю «соціальна філософія та філософія історії» (2012). У цьому контексті він згадує імена сучасних українських філософів, сферою наукових зацікавлень яких є «національний менталітет» - «М. Поповича, П. Гнатенко, О. Донченко, В. Храмову. Сучасні українські вчені В. Андрущенко, В. Арбеніна, В. Бебик, А. Бичко, І. Бичко, Н. Вяткіна, В. Горський, Р. Додонов, Б. Евтух, С. Головаха, С. Кримський, А. Кавалеров, О. Лісеєнко, О. Майборода, М. Мищенко, Л. Нагорна, В. Омельянчик, Т. Поплавська, Ю. Писаренко, О. Стовпец, Т. Рудніцка, О. Степаненко, В. Храмова, С. Шульга та ін.» [23, с. 8]. Висновки щодо актуальності розгляду тематики архетипу саме в соціально-філософському контексті підтримують і інші сучасні українські філософи. Так, А. Рубан у дисертації на здобуття вченого ступеня кандидата філософських наук за спеціальністю «філософська антропологія, філософія культури» (2008) відзначає: «Зміст ментальності, досягнувши вищих рівнів духовного життя розчиняється у національному характері, у суспільній думці, у формах суспільної свідомості, у змісті інституційного рівня духовного виробництва в формах архетипів, символів, ритмів, симпатій і антипатій» [18, с. 16]. Неусвідомленість і безпосередня «неоформленість» архетипу лише додає таким науковим пошукам актуальності (Н. Ковтун [див.: 8]) і є під- 
ставою для філософського аналізу у цьому напрямку в майбутньомy.

Об'єктом нашого дослідження є аналіз феномена архетипу як частини сучасного українського філософського дискурсу. Предметом - соціально-філософські рецепції теми архетипу як феномена, що має соціальну специфіку. Метою дослідження є, по-перше, аналіз актуального стану сучасного українського соціальнофілософського дослідження архетипу; по-друге, обгрунтування його актуальних позитив та соціально-філософських рецепцій 3 огляду на міждисциплінарність аналізу архетипу і його метаграничність; i, по-третє, визначення перспектив використання архетипного підходу як частини методологічного дискурсу в українських соціально-філософських рецепціях майбутнього. Сукупність цих завдань і становить наукову новизну дослідження, яке має оглядово-аналітичний характер. Методологічною основою є метод аналітико-синтетичного опрацювання документів (АСОД), завдяки якому оглянуто проблематику архетипу у філософських дослідженнях двох останніх десятиліть, визначено тенденції та перспективи застосування архетипного підходу у соціально-філософських дослідженнях.

Сучасний «соціально-філософський дискурс (discursus: от лат. Discursus - міркування) це: 1) вербально артикульований спосіб об'єктивації змісту поліетнічного соціуму як складного соціального феномена, що регулюється домінуючим у тій чи іншій соціокультурній традиції типом раціональності; 2) сукупність смислів, когнітивних та ціннісних значень, що є основою культури суспільства, охоплює всі форми комунікативної активності людини, iii рефлексією щодо політичного світу та своєї ролі в ньому; 3) культурні артефакти, реалізовані у філософській символіці; 4) інституційні та неінституційні (особистісно орієнтовані) форми спілкування, в яких суб'єкт, адресат або зміст спілкування належать до сфери філософського осягнення дійсності» і т.д. (М. Максименюк) [14, с. 225]. Звернення до наведених тут елементів соціально-філософського дискурсу у філософських дослідженнях 3 інших спеціальностей можна вважати рецепціями (від лат. «receptio» - прийом, прийняття) - сприйняттям, запозиченням, від- 
творенням, перетворенням смислів та понять [26]. У цьому контексті, справді, «архетип та принципи його феноменологічного розгортання представляють собою природню діалектику взаємодії суспільної форми буття індивіда та людства і змісту їх свідомого самоосвоєння», як відзначає А. Некита у дисертації 2001 р. кандидата філософських наук за спеціальністю «соціальна філософія та філософія історії» [16, с. 12]. I саме тому ми вважаємо, що праці сучасних українських вчених, які розробляли тематику архетипу, окреслюють його 3 різних боків як соціокультурний феномен. Серед наукових спеціалізацій такого аналізу - історія філософії, філософська антропологія та філософія культури, а також політологія, українознавство, державне управління, філософія освіти, мовознавство, мистецтвознавство та ін. На те, що «аналіз проблемного поля індивіда, архетипова детермінація української та російської культур здійснено в працях М. Поповича, В. Кременя, В. Малахова, Н. Корабльової», у 2002 р. звертає увагу Н. Чеботарьова у дисертації кандидата філософських наук за спеціальністю «соціальна філософія та філософія історії» [21, с. 5].

Простий пошук у системі Google на запит-поєднання ключових слів «архетип» and «соціально-філософський» and «український» and «дисертація» видає результат в 69700 позицій (станом на 23.07.2020). При додаванні маркера «2010» утворюється цифра в 43600 , з маркером «2011»-44 600, з маркером «2013»-43 600, 3 маркером «2014» - 46 300, з маркером «2015»-43 900, з маркером «2016» - 31 100, з маркером «2017» - 26 700, маркер «2018» дає 21300 результатів, маркер «2019» - 18 700, i, нарешті, маркер «2020» - 25300 результатів [25]. Водночас на сайті наукової бібліотеки Національного педагогічного університету імені М. П. Драгоманова у режимі вільного пошуку за маркерами «архетипи» and «соціально-філософський» знаходиться 11283 результати, а при додаванні маркеру «український» стає 29499 позицій [27]. Зрозуміло, що жодна наведена статистика не $\epsilon$ навіть близько репрезентативною. Для того, щоб зрозуміти більш-менш реальну ситуацію, необхідно промоніторити персональні списки праць вчених у базах Google Scholar, Publons, Orcid, Web of Science; сайти підрозділів університетів та дослідницьких установ по всій Україні, списки дисертацій, поданих на затвердження в МОН, перегля- 
нути теми науково-дослідних робіт та плани проведення конференцій і круглих столів, проаналізувати зміст монографій (одноосібних та колективних), фахових журналів, збірників праць, а також методичних комплексів і контент інтернет-ресурсів, на яких проводяться вебінари, тренінги, презентації. Кожен дослідницький проект у цьому ракурсі постає як цілий мультиверсум соціальнофілософських категорій, пов'язаних спільною ідеєю інваріантів духовного життя людини, що впливають на соціальні, суспільні, культурні, державні процеси. Якщо ж все таки поставити завдання виявити узагальнену картину соціально-філософських рецепцій феномена архетипу в Україні за останні 10 років, то база Google Scholar дає можливість це зробити більш коректно, з огляду на те, що не лише показує приблизну кількість джерел, а й виявляє кількість копій, цитувань і сама цитує відповідні місця у працях. Зазначимо, що категоріальний науковий апарат, пов'язаний 3 концептом «архетипу», включає в себе «суміжні концепти» міфу, символу, цінності, паттерну, символічного образу, а розгляд феномена архетипу в контексті аналізу «ідеї» та «діяльності» дає безмежне поле для поєднання смислів і конструювання методологічних підходів та методик.

Отже, список бібліографічних посилань, доступних базі даних Google Scholar, налічує станом на 23.07.2020 p. 41 сторінку. Ми наведемо ці дані як нерелевантну нерепрезентативну статистику - цифри, без яких все ж масштаб соціально-філософської рефлексії над тематикою архетипу в сучасній Україні поряд із іншими темами досліджень буде невідчутним.

Посилання на джерела у базі Google Scholar (2010-2020 pp.)

\begin{tabular}{|c|c|c|c|}
\hline & $\begin{array}{c}\text { Архетип and co- } \\
\text { ціально- } \\
\text { філософський and } \\
\text { український }\end{array}$ & $\begin{array}{c}\text { Архетип and со- } \\
\text { ціально- } \\
\text { філософський }\end{array}$ & Архетип \\
\hline $2010-2011$ & 55 & 64 & 18100 \\
\hline $2011-2012$ & 74 & 82 & 14800 \\
\hline $2012-2013$ & 86 & 102 & 19300 \\
\hline
\end{tabular}


ISSN 2078-8142 Мультиверсум. Філософський альманах. 2020. Випуск 1(171). Том 2.

\begin{tabular}{|c|c|c|c|}
\hline $2013-2014$ & 89 & 111 & 14600 \\
\hline $2014-2015$ & 95 & 121 & 20400 \\
\hline $2015-2016$ & 88 & 114 & 14800 \\
\hline $2016-207$ & 82 & 103 & 21200 \\
\hline $2017-2018$ & 74 & 88 & 14900 \\
\hline 2018-2019 & 82 & 92 & 20500 \\
\hline $\begin{array}{c}\text { 2019-2020 } \\
\text { Разом 3а } \\
\text { період } \\
\text { 2010-2020 }\end{array}$ & 61 & 70 & 15400 \\
\hline
\end{tabular}

Наведена статистична інформація лише ілюструє розгортання кількох методологічних процесів щодо визначення ролі феномена архетипу в українській соціально-філософській парадигмі:

1. Появу зацікавлення феноменом архетипу на тлі глобального інтересу світової наукової спільноти до архетипу взагалі (у різних його проекціях);

2. Тривалість цього процесу у часі (загалом спад інтересу дослідників пов'язаний, на нашу думку, зі станом інституцій в Україні, соціокультурними процесами дезадаптації в українському суспільстві та складним становищем сучасної людини у світі, що засвідчує, зокрема, колективна монографія «Людина в складному світі...» [13)];

3. Розгляд феномена архетипу в якості методологічного концепту соціально-філософського знання, що здатний надати дослідженням соціальної реальності необхідної їм якісної визначеності, стати не лише «коренем суспільного буття», а й коренем соціально-філософської методології;

4. Обирання концепту архетипу як методологічної складової соціально-філософського аналізу саме українського соціального тла та властивих йому процесів (за даними статистики, частка та- 
ких україно-орієнтованих досліджень серед соціальнофілософських становить щороку не менше 60\%).

Оскільки динамічна картина, ілюстрована статистичною викладкою, справедливо викликатиме сумніви у репрезентативності, ми наведемо паралельно аргумент географічного поширення (територіальний аспект) соціально-філософських досліджень феномена архетипу. Для такої ілюстрації оберемо з усього масиву наукової літератури, виданої останнім часом в Україні з проблематики архетипу, збірку «Публічне управління: теорія та практика: збірник наукових праць Асоціації докторів наук з державного управління» (2014) [17] - одне з низки видань дослідницької «Української школи архетипіки», яка концептуалізувала і розвинула архетипний niдxid через створення власне активної наукової спільноти. Вона ілюструватиме, по-перше, статусність, по-друге, поширеність, і потретє, розгалуженість архетипно-грунтованих досліджень соціальних явищ. Так, віце-президент Національної академії державного управління при Президентові України проф. М. Білінська у передмові до цього видання зазначає: «Українська школа архетипіки об'єднує понад 150 докторів і кандидатів наук, аспірантів, докторантів, магістрантів і незалежних дослідників, котрі - представники найважливіших сфер соціально-гуманітарного знання з 12 країн світу. Сьогодні цілком можна говорити про сформоване наукове співтовариство, сукупний результат діяльності якого становлять близько 250 наукових публікацій, в тому числі ряд монографій i докторських дисертацій в галузі наук державного управління. За підсумками теоретико-методологічних семінарів готуються резолюції та рекомендації для органів державної влади» $[17$, с. 5].

Тематичний аналіз матеріалів даних двох джерел - наведеної інформації із сайту Google Scholar та досліджень у збірнику "Публічне управління...» дає змогу виокремити «смислові рубрики» у системі рецепцій сучасних українських філософів щодо феномена архетипу. У даному поданні значення «порядку» чи пріоритету така рубрикація не має, крім спроби визначити спрямування дослідницьких інтересів. Найбільш «активними» є розробки у сфері дослідження: української ментальності; трансформаційних процесів сучасності; соціокультурних практик; державного будівництва 
(публічного адміністрування або управління); соціокультурних традицій; соціальних структур; екзистенціалів суспільного буття; колективного несвідомого; історичних традицій; проблем забезпечення рівності (в основному стосовно гендерних проекцій). Існує i категорія інтегративних праць, в яких поєднуються перелічені тематики (наприклад, монографія проф. М. Козловця «Феномен національної ідентичності: виклики глобалізації» [10]). Вони є репрезентацією не окремого феномена, а зв'язку феноменів, і становлять значний інтерес.

Загалом це дає можливість зробити висновки щодо актуальності дослідження архетипів у соціально-філософському аспекті.

По-перше, поняття «архетипу» є базою для наукових дискусій, що сприяє розвитку сочіогуманітарного знання в цілому. Наукові заходи, що проводяться в Україні, підтверджують ефективність трансдисциплінарності у форматі міжнародного наукового співробітництва та дієвість традицій освітнього учнівства. Феномен архетипу приваблює наукове молоде покоління саме широтою «репертуару рецепцій», і в тому числі як частини наукової практики передання знань від доктора, професора, до аспіранта, пошукача [1, с. 16]. Рельєфно висвітлюють актуальність пошуку нових підходів у соціально-філософському дискурсі автори колективного навчального посібника, в якому саме міждисциплінарний дискурс $\epsilon$ «родзинкою» сучасних підходів до методологічних завдань: «На порядок денний знов вийшла споконвічна філософська проблема вибору людиною шляху, що веде їі до добра чи зла. Вирішити цю ситуацію нині можливо лише через інновацію людського розуму і моралі. Водночас стало очевидним, що дотримання лише традиційних етичних принципів у науковій діяльності й медичній практиці не завжди дає позитивні результати. Це означає, що всі традиційні етичні регулятори науки й медицини самі потребують нового підходу, нового трактування цілої низки проблем медицини» («Соціально-філософські та етичні проблеми медицини...» 2010 р.) [19, с. 5]. До таких підходів, на нашу думку, слід зарахувати архетипний, а у поєднанні з кониептом «цінність» в якості архетипноціннісного, він може стати незамінним інструментом аналізу транста мета-інтегративних соціальних систем. 
По-друге, для наукового аналізу зв'язку архетипу та інших сочіальних явищ застосовними є як методи загальнонаукового, зокрема гуманітарного, дослідження, так і специфічно сочіальнофілософські методи, щуо уможливлює не лише міждисциплінарний «діалог інтерпретацій» на рівні теорій, а й створення практичних корелятивних моделей сочіального буття з великим діапазоном часово-просторових параметрів. Так, у дослідженні «Особливості методології наукового пізнання» визначено поняття «архетип наукового мислення», яке автори А. Культенко та О. Радовільська також розкривають як «архетип теоретичного мислення». На їхню думку, його складовими є поняття «стиль мислення» та «картина світу», що дає вихід у широкі сфери соціософського та соціокультурологічного знання. «Під поняттям «архетип теоретичного мислення» - зазначають дослідники, - розуміють сукупність принципів, які на конкретному історичному етапі розвитку науки задають певний спосіб теоретичної діяльності для пояснення явищ, визначають вибір засобів цієї діяльності, відбір та прийняття іiі кінцевих результатів, а також задають певне бачення світу, спосіб його відображення в науковому пізнанні, що в єдності визначає і певний тип теоретичного мислення, і сукупність допустимих заходів теоретичної діяльності» [11, с. 189]. Дослідження архетипу часто грунтуються на принципі системності [16], об'єктивності, історизму, причинності, зіставлення, порівняння, загального зв'язку і розвитку [18]; використовуються також аналіз наскрізних структур, соціально-психологічний аналіз, герменевтичний підхід, феноменологія, порівняльно-історичні дослідження [7]; інтегрований підхід, «який поєднує на комплементарних засадах синергетичний, діалектичний, когнітивний, системний підходи» [20, с. 3].

По-третє, на рівні сочіально-філософського аналізу глобальних сочіальних утворень та прочесів в украӥнській філософії останнього десятиліття архетипна складова виокремлюється як системоутворювальна. Так, науковою новизною захищеної у 2015 р. О. Сташкевич дисертації на здобуття наукового ступеня кандидата філософських наук за спеціальністю 09.00.03 «Інтелектуальна цивілізація: соціально-філософський аналіз» $є$ «доведена гіпотеза, що форма буття смислу в континуумі Семантичного Все- 
світу визначає тип цивілізації, оскільки історичний розвиток планетарної спільноти проходить декілька етапів, котрі детермінуються і пояснюються здатністю планетарної людини засвоювати ланцюг перетворень змісту Семантичного Всесвіту по лінії: архетипи - емпіричне знання - наукове знання - інформація - смисли - «космічне смислотворення» [20, с. 4]. В авторському поясненні алгоритмів життєдіяльності людства використовуються, поряд 3 терміном «архетип», також концепти «пралюдина», «індивід», «людська особистість», «планетарне людство як особистість», «ноосферна особистість», «променеве людство», «планетарна спільнота», «вісь Семантичного континууму» та інші. Космічна цивілізація, на думку О. Сташкевич, є продовженням цивілізаційного розвитку не лише інтелектуальної цивілізації найближчого майбутнього, а й архетипної «працивілізації» далекого минулого. У дисертації 2010 р. доктора наук за спеціальністю 09.00.03 О. Сременка запропоновано терміни «архетипна подія», «архетипна програма», «архетипний взірець», а у підрозділі «Архетипне, номіналістичне і естетичне розуміння «подієтеми»» розвинено й деталізоване вчення про подієтему [6, с. 22]. Така методологія утворює наскрізну «сітку», в якій соціальне згортається і розгортається у різних проекціях, але завжди у системотворчій (власне соціальнофілософській) рецепції.

По-четверте, вагомим методологічним значенням наділяють архетипний підхід $і$ у царині украӥнського суспільнотворення як практичного завдання науки: «Бачення національної ідеології як проекту життєтворення суспільства тісно переплетені з етнокультурною міфотворчістю та вивченням архетипів. Метод архетипів істотно відрізняється від інтуїтивно-психологічних міркувань про душу народу, - підкреслює В. Веденєєв. - ... На цьому архетиповому підгрунті можна вибудувати історичну перспективу української спільноти, враховуючи взаємодію різних соціально-політичних утворень у сучасних глобалізаційних реаліях» [2, с. 128]. У дисертації 2004 р. кандидата філософських наук за спеціальністю 09.00.03 О. Горбаня «Стратегема сталого розвитку суспільства (соціально-філософський аналіз)» «виявлена і розглянута сталість буття соціуму на основі архетипного зв'язку етносу і довкілля. На основі аналізу етнографічного матеріалу, виявлені екологічні па- 
раметри архетипів української ментальності як передумови сталого розвитку даного антропогеоценозу» [4, с. 13]. Автор дисертації доктора філософських наук за спеціальністю 21.03.01 «Національна безпека в умовах соціальних трансформацій (теоретикометодологічний аналіз» (2005) О. Дзьобань визначив низку апробаційних матеріалів, ключовим поняттям яких є «соціальний архетип», що розглядається у різних площинах: у контексті безпеки соціальної системи та в контексті культури. Висновки дослідника можуть стати концептуальними засадами методології оприявнення соціальних параметрів архетипу у процесі вирішення практичних проблем сучасного українського кризового соціуму [5]. У своїй дисертації 2002 р. кандидата філософських наук за спеціальністю 09.00.03. Н. Чеботарьова підкреслює, що «ненасилля, як явище суспільного життя, ідеологічний принцип, соціальний ідеал, механізм соціальної регуляції та засіб розв'язання конфліктів уявляє соціальний архетип і атрибут соціального морфогенезу, що задає основоположні “смисли” цивілізованому співжиттю людей» [21, с. 8]. А дослідник національного менталітету Хоанг Тхи Кук у дисертації 2012 р. кандидата філософських наук за спеціальністю 09.00.03 так викладає новизну власного дослідження: «Визначення «національного менталітету» пов'язане з іманентною етнокультурною цілісністю, котра вміщує сукупність історично сформованих установок і рис характеру народу, цінностей, стереотипів і архетипів, які мають специфіку поведінкового прояву», виявляючи далі як уточнене «уявлення про основні складники національного менталітету: «архетипічний» - система архетипів і компонентів колективного несвідомого; когнітивний - образ світу і способи мислення колективного суб'єкта; ціннісно-смисловий - система цінностей, ціннісних орієнтацій, значень, норм; емоційний - оцінки, настрої, емоції, почуття; поведінковий - мотиви і стереотипи поведінки» [23, с. 4]. Це означає, що такий підхід вже не є абсолютною новацією, але повинен розвиватися далі, щоб поступово перейти в якість традиції соціально-філософської методології.

Говорити про універсальність архетипу як методологічного соціально-філософського конструкта дає можливість його феноменальна природа, концептуалізована О. Любчук та В. Шостаком у 
такій рецепції: «Рівночасно архетипові форми міфологічного минулого є і ціннісно-ієрархічними формами, і позбавленими релятивності формоутвореннями. Архетип утілює дійсність у процесі, зміні. Він $є$ потенційно досягненим у діалектично відкритому просторово-часовому континуумі майбутнього. Як позачасовий механізм передавання духовних надбань архетип утримує визначеність, доки деструктивні сили не спричиняють його дезактуалізацію. Із часом структурні складники архетипу перегруповуються, трансформуються в інші архетипи або до певного часу зникають, а за певних умов знову виринають на рівні індивідуальної та суспільної свідомості. Пророча заданість архетипових форм покликана задавати смисл майбутніх часів, а не жорстко визначати майбутні факти. Тому будь-які передбачення мають тлумачити смисл розвитку, а не лише його фактичне наповнення. Потрапляючи на історичний грунт, архетип наповнюється змістом відповідно до соціальнокультурного оточення. Через архетип можна висловити безкінечне чи остаточне, надати йому буття у формі конечного, конкретного образу. Водночас архетип не локалізований у реальному історичному процесі, а утримує в собі всю повноту часів» [12, с. 41]. Отже, у перспективі його дослідження здатне створити новий «горизонт смислів» саме у соціально-філософській рецепції: адже здавна «міфологічне смислопородження, створюючи у цілому ілюзорну картину світу, у кінцевому підсумку виконувало конструктивні функції, згуртовувало людей, допомагало орієнтуватися у ворожому для них світі протягом багатьох тисячоліть. Хоча, за великим рахунком, ці уявлення мали ілюзорно-фантастичний характер, тим не менш, вони допомагали вирішувати завдання виживання і розвитку людських спільнот i окремої людини» (В. Шаповал [24, с. 85]). Щодо категоризащії феномену архетипа, то наведемо лише кілька, згідно з обсягом статті, соціально-філософських його рецепцій сучасними українськими філософами. Архетип «святості» та архетип «софійності» конотовано проф. Н. Ковальчук поміж інших (архетип «серця», архетип слова» та інших, виокремлених проф. С. Кримським) [7]. Архетип Героя часто стає об'єктом наукового аналізу, зокрема соціально-філософського, саме українських дослідників. Так, проф. Н. Ковтун вказує як на джерела з'ясування історико-філософського підгрунтя архетипу культурно- 
го героя в українській духовній традиції «праці А. Бичко, В. Войтовича, О. Гриценка, В. Давидюка, М. Котляра, С. Кримського, М. Поповича, Н. Хамітова» [8, с. 2]. Але лише цим архетипом далеко не вичерпується перелік об'єктів архетипного аналізу вказаних авторів. Так, проф. Н. Хамітов також стверджує, що «метаантропологія і постантропологія як теорії і практики самореалізації особистості уособлені в архетипах доктора Фауста i доктора Вагнера», а також виокремлює «духовні та душевні архетипи» - Геній, Герой, Святий. Ми погоджуємося і $з$ першим, і 3 другим поділом [22, с. 8]. Типології архетипів у сучасній соціогуманітарній науці вельми розгалужені і потребують окремого розгляду.

Отже, доходимо загального висновку: завдання соціальнофілософського дослідження феномена архетипу в контексті його зв'язку з різними соціогуманітарними феноменами становить один 3 напрямів розвитку української філософії майбутнього. Рецепція архетипно-ціннісним підходом соціально-філософських смислів дає можливість досягти перспективної мети «внесення людиною сенсу у навколишній світ... : - на індивідуальному рівні: набуття точки опори, рівноваги власної душі; - на соціальному рівні: досягнення єдності та згуртованості соціальної групи, до якої належить індивід, без чого виживання і успішне існування у навколишньому світі неможливе» [24, с. 93]. Ці завдання цілком корелюють із принципами, обгрунтованими Н. Хамітовим в якості методологічного вектора для соціального аналізу.

\section{ЛIТЕРАТУРА}

1. Архетипіка і державне управління: раціоналізація та нормативні практики. Збірник наукових праџьь переможиів $і$ кращих авторів Другого міжнародного конкурсу молодих учених. Київ, 13 червня 2014 р. / ред. Е. А. Афоніна, Г. Л. Рябцева. К. : Псіхєя, 2014. 120 с.

2. Веденєєв В. О. Теоретичні засади соціокультурного виміру сучасного процесу самоідентифікації громадян України. Грані. 2014. № 6 (110) червень. С. 125-130. 
3. Гапеєва О. Л., Кисіль В. В. Українська національна ідея: бібліографічний огляд сучасних поглядів. Вісник Національної академії оборони. 2010. Вип. 5 (18). С. 11-16.

4. Горбань О. В. Стратегема сталого розвитку суспільства (соиіально-філософський аналіз): Автореферат дисертації на здобуття наукового ступеня кандидата філософських наук за спеціальністю 09.00.03 соціальна філософія та філософія історії. Таврійський національний ун-т ім. В. І. Вернадського. Сімферополь, 2004. 18 с.

5. Дзьобань О. П. Національна безпека в умовах соціальних трансформацій (теоретико-методологічний аналіз). Дисертація на здобуття наукового ступеня доктора філософських наук за спеціальністю 21.03.01 - гуманітарна і політична безпека держави. - Національний інститут стратегічних досліджень. Київ, 2005. 32 с.

6. Сременко О. М. Історична подія у контексті європейської традииії (сочіально-філософський аналіз). Дисертація на здобуття наукового ступеня доктора філософських наук за фахом 09.00.03 - соціальна філософія та філософія історії. Дніпропетровський національний університет імені Олеся Гончара. Дніпропетровськ, 2010. 34 с.

7. Ковальчук Н. Д. Символічні структури етнокультурного процеcу в Україні. Дисертація на здобуття наукового ступеня доктора філософських наук за фахом 09.00.04 - «філософська антропологія, філософія культури». - Інститут філософії імені Г. С. Сковороди Національної Академії Наук України. Київ, 2007. 20 с.

8. Ковтун Н. М. Архетип культурного героя в українській духовній традииії: історико-філософський контекст. Авторефрат дисертації на здобуття наукового ступеня кандидата філософських наук за спеціальністю 09.00.05 - історія філософії. Київський національний університет імені Тараса Шевченка. Київ, 2008. 20 с.

9. Кожем'якіна О. М. Архетипні засади комунікативних практик маніпулювання довірою. Публічне управління: теорія та практика. 3бірник наукових працьь Асоиіачії докторів наук з державного управління: Спеціальний випуск. Харків : Вид-во «ДокНаукДержУпр», 2012. С. 263272.

10. Козловець М. А. Феномен національної ідентичності: виклики глобалізації. Житомир : Вид-во ЖДУ ім. І. Франка, 2009. 558 с.

11. Культенко В. П., Радовільська О. О. Особливості методології наукового пізнання. Гілея: науковий вісник. 2020. Вип. 152 (1). С. 18-190.

12. Любчук О., Шостак В. Феномен архетипу: трактування, прояви й роль у національній культурі. Науковий вісник Східноєвропейського національного університету імені Лесі Українки. 2013. № 11. С. 38-42. 
13. Людина в складному світі / ред. Н. В. Кочубей, М. О. Нестерової; вступне слово В. П. Адрущенка. Суми : Університетська книга, 2017. 357 с.

14. Максименюк М. Ю. Соціально-філософський дискурс розвитку поліетнічного соціуму. Гуманітарний вісник Запорізької державної інженерної академіï. 2010. Вип. 40. С. 224-238. URL: http://nbuv. gov.ua/UJRN/znpgvzdia_2010_40_24

15. Менжулін В. Нові пригоди архетипів: спадщина Карла Юнга в інтерпретаціях українських дисертантів-філософів. Актуальні проблеми духовності. Збірка наукових пращь. Кривий Ріг, 2005. С. 11-128.

16. Некита А. Механізми несвідомого соціального спотворення феноменології архетипу. Автореферат дисертації на здобуття наукового ступеня кандидата філософських наук за спеціальністю 09.00 .03 - соціальна філософія та філософія історії. Інститут філософії імені Г.С.Сковороди Національної Академії Наук України. Київ, 2001. 14 с.

17. Публічне управління: теорія та практика. Збірник наукових праць Асоціації докторів наук з державного управління. Харків : Вид-во «ДокНаукДержУпр». 2014. № 2(18) спеціальний випуск. 244 с.

18. Рубан А. О. Світоглядні особливості українського національного характеру (філософсько-антропологічний аналіз). Автореферат дисертації на здобуття наукового ступеня кандидата філософських наук за спеціальністю 09.00.04 - філософська антропологія, філософія культури. Національний педагогічний університет імені М. П. Драгоманова. Київ, 2008. 20 c.

19. Соціально-філософські та етичні проблеми медицини: Навч. Посібник / заг. ред. А. П. Алексеєнко, В. М. Лісового. Харків : Колегіум, 2010. $340 \mathrm{c}$.

20. Сташкевич O. О. Інтелектуальна цивілізація: соціальнофілософський аналіз. Авторефрат дисертації на здобуття наукового ступеня кандидата філософських наук за спеціальністю 09.00.03 - соціальна філософія та філософія історії. Інститут вищої освіти Національної академії педагогічних наук України. Київ, 2015. 21 с.

21. Чеботарьова Н. В. Феномен агресії в людському досвіді: соціально-філософський вимір. Автореферат дисертації на здобуття наукового ступеня кандидата філософських наук за спеціальністю 09.00.03 - соціальна філософія та філософія історії. Харківський військовий університет. Харків, 2002. 14 с.

22. Хамітов Н. В. Перспективи самореалізації особистості: проекти метаантропології і постантропології. Майбутнс особистості та сім'ӥ: контексти філософської антропологї̈, психоаналізу, арт-терапії та фi- 
лософської публічистики. Підхід філософської антропологї̈ як мета антропології: збірник наукових праць / ред. Н. В. Хамітов. Київ : Інтерсервіс, 2019. С. 7-25.

23. Хоанг Тхи Кук. Національний менталітет в умовах трансформації сучасного українського суспільства. Автореферат дисертації на здобуття наукового ступеня кандидата філософських наук за спеціальністю 09.00.03 - соціальна філософія та філософія історії. Державний заклад «Південноукраїнський національний педагогічний університет імені К. Д. Ушинського. Одеса, 2012. 23 с.

24. Шаповал В. Про сенс та безглуздість сущого. Філософські обpiï. 2012. № 28. C. 84-93.

25. Пошук у базі даних Google Scholar. URL: https://scholar.google.com/scholar?hl=ru\&newwindow=1\&as_sdt=0\%2C5\&as _ylo=2010\&as_yhi=2020\&q=\%D0\%B0\%D1\%80\%D1\%85\%D0\%B5\%D1\%8 2\%D0\%B8\%D0\%BF+\%D1\%81\%D0\%BE\%D1\%86\%D1\%96\%D0\%B0\%D0 \%BB\%D1\%8C\%D0\%BD\%D0\%BE-\%D1\%84\%D1\%96\%D0\%BB\%D0\% BE\%D1\%81\%D0\%BE\%D1\%84\%D1\%81\%D1\%8C\%D0\%BA\%D0\%B8\%D0 \%B9+\%D1\%83\%D0\%BA\%D1\%80\%D0\%B0\%D1\%97\%D0\%BD\%D1\%81\% $\mathrm{D} 1 \% 8 \mathrm{C} \% \mathrm{D} 0 \% \mathrm{BA} \% \mathrm{D} 0 \% \mathrm{~B} 8 \% \mathrm{D} 0 \% \mathrm{~B} 9+\& \mathrm{btnG}=($ дата звернення 23.07.2020).

26. Рецепція. URL: http://enc.com.ua/medicina/rezi-riz/25888recepciya.html

27. DSpace at library NPU Dragomanova. URL: http://enpuir.npu. edu.ua/simple-search (дата звернення 23.07.2020).

\section{REFERENCES}

Afonin E. A., Ryabtsev G. L. (Eds). (2014). Archetype and public administration: rationalization and normative practices.Zzbirnyk naukovykh prats' peremozhtsiv i krashchykh avtoriv Druhoho mizhnarodnoho konkursu molodykh uchenykh (Collection of scientific works of winners and best authors of the Second International Competition of Young Scientists). Kyiv, 120. [In Ukrainian].

Vedenyeyev, V. O. (2014). Theoretical basis of sociocultural dimension modern process of self-identification citizens of Ukraine. Hrani (Grani), № 6(110) cherven, 125-130. [In Ukrainian].

Hapeyeva O .L., Kysil' V .V. (2010). Ukrainian national idea: bibliographic review of modern views. Visnyk Natsional'noyi akademiyi oborony (Bulletin of the National Defense Academy). 5 (18), 11-16. [In Ukrainian]. 
Gorban', A. V. (2004). "Stratagem of sustainable development of a society (the socially-philosophical analysis)". Abstract of the dissertation on competition of a scientific degree of the candidate of philosophical sciences on a speciality 09.00.03 - Social philosophy and philosophy of a history. Tavricheskiy National University of V. I. Vernadskiy. Symferopol. 18. [In Ukrainian].

Dzeban, A. P. (2005.) National security in conditions of social transformation (theoretic and methodological analysis). Dissertation for the Doctor's scientific degree in Philosophpical Sciencees in speciality 21.03.01 - humanitarian and political security of the state. National Institute for Strategic Studies. Kyiv. 32. [In Ukrainian].

Yeremenko, A. M. (2010). Historical event in the context of European tradition: social-philosophical analysis. Thesis for the Doctoral Degree in Philosophy Speciality 09.00.03 - Social Philosophy and Philosophy of History. Dnepropetrovsk Oles Gonchar National University. Dnepropetrovsk. 34. [In Ukrainian].

Kovalchuk, N. D. (2007). Symbolic Structures of Ethnocultural Process in Ukraine. Thesis for taking the degree of Doctor of Philosophical Sciences. Specialization 09. 00. 04 - philosophical anthropology, philosophy of culture. Institute of Philosophy named G.Skovoroda of National Academy of Sciences of Ukraine. Kyiv. 20. [In Ukrainian].

Kovtun, N. M. (2008). Archetype of the cultural hero in Ukrainian spiritual tradition: historical-philosophical context. Manuscript. Dissertation for obtaining the scientific degree of the Candidate of Science in Philosophy. 09.00.05. History of Philosophy. Taras Shevchenko Kyiv National University. Kyiv. 26. [In Ukrainian].

Kozhemyakina, O. M. (2012). Archetypal principles of communicative practices of trust manipulation. Public administration: theory and practice. Proceeding of the Association of Doctors of Science in Public Administration: Sprcial Issue. Kharkiv, pp. 263-272. [In Ukrainian].

Kozlovets, M. A. (2009). The phenomenon of national identity: the challenges of globalization. Zhytomyr: Vyd-vo ZHDU im. I. Franka. 558. [In Ukrainian].

Kultenko, V. P., Radovilska, O. O. (2020). Features of scientific knowledge methodology). Hileya: naukovyy visnyk (Hileya: scientific herald). Vol. 152 (1). 18-190. [In Ukrainian].

Lyubchuk, O., Shostak, V. (2013). The Phenomenon of Archetype: Interpretation, Manifestation and Role of the National Culture. Naukovyy visnyk Skhid- 
noyevropeys'koho natsional'noho universytetu imeni Lesi Ukrayinky (Scientific Bulletin of the Lesia Ukrainka East European National University). № 11. 3842. [In Ukrainian].

Kochubey, N. V., Nesterova, M. O. (Eds.) (2017). Human in Complexity. Sumy: Universytets'ka knyha, 357. [In Ukrainian].

Maksymenyuk, M. Yu. (2010). Socio-philosophical discourse of development of polyethnic society. Humanitarnyy visnyk Zaporiz'koyi derzhavnoyi inzhenernoyi akademiyi (Humanities bulletin of Zaporizhzhe State Engineering Academy). Vip. 40. 224-238. Retrieved from http://nbuv.gov.ua/UJRN /znpgvzdia_2010_40_24 [In Ukrainian].

Menzhulin, V. (2005). New adventures of archetypes: the legacy of Carl Jung in the interpretations of Ukrainian dissertations-philosophers. Aktual'ni problemy dukhovnosti. Zbirka naukovykh prats' (Actual problems of spirituality. Collection of scientific works). Kryvyi Rih. 11-128. [In Ukrainian].

Nekita, A. (2001). Mechanisms of unconscious social transformation phenomenology of archetype. Abstract of the dissertation for obtaining of degree of bachelor of philosophic science on speciality 09.00.03 - social philosophy and philosophy of history. Institute of Philosophy, Ukrainian Academy of Sciences. Kiev. 14. [In Ukrainian].

Public administration: theory and practice: a collection of scientific works of the Association of Doctors of Science in Public Administration (2014). Kharkiv: Vyd-vo “DokNaukDerzhUpr”. № 2 (18) special issue. 244. [In Ukrainian].

Ruban, A. O. (2008). Worldview features of the Ukrainian national character (philosophical and anthropological analysis). Abstract of the Dissertation to achieve the Degree of the Candidate of Philosophical Science in speciality 09.00.04 - Philosophical Anthropology, Philosophy of Culture. The National Pedagogical University named after M. P. Drahomanov. Kiev. 20. [In Ukrainian].

Alekseenko, A. P., Lisovy, V. M. (Eds.) (2010). Socio-philosophical and ethical problems of medicine: Textbook. Manual. Kharkiv: Kolehium. 340. [In Ukrainian].

Stashkevich, O. (2015). Intellectual Civilization: Philosophical and Social Analysis. Abstract of the dissertation for the degree of candidate in philosophical sciences by speciality 09.00 .03 - social philosophy and philosophy of histo- 
ry. Institute of Higher Education of the National Academy of Pedagogical Sciences of Ukraine. Kyiv. 21. [In Ukrainian].

Chebotaryova, N. V. (2002). The phenomenon of aggression in human experience: socialy-philosophical measurement. Abstract of a Candidate of Philosophy dissertation in the speciality 09.00.03 - social philosophy and history of philosophy. Kharkiv military university. Kharkiv. 14. [In Ukrainian].

Khamitov, N. V. (Ed.) (2019). Perspectives of self-realization of personality: projects of metaanthropology and postanthropology. The future of personality and family: contexts of philosophical anthropology, psychoanalysis, art therapy and philosophical journalism. The approach of philosophical anthropology as the purpose of anthropology: a collection of scientific works. Kyiv: Interservice. 264. 7-25. [In Ukrainian].

Hoang Thi Cuc (2012). National mentality in the conditions of transformation of the modern Ukrainian Society. Abstract of the thesis for a candidate's degree in philosophical Science. Speciality 09.00.03. - Social philosophy and philosophy of history. State Institution "The South Ukrainian National K. D. Ushinsky Pedagogical University. Odessa. 23. [In Ukrainian].

Shapoval, V. N. (2012). About sense and nonsense pure. Filosofs'ky obrii. Naukovo-teoretychny zhurnal. Vypusk 28. Kyiv-Poltava, 84-93. [In Ukrainian].

Retrieved from https://scholar.google.com/scholar?hl=ru\&new window $=1 \& a s \_s d t=0 \% 2 C 5 \& a s \_y l o=2010 \& a s \_y h i=2020 \& q=\% D 0 \% B 0 \% D 1 \%$ 80\%D1\%85\%D0\%B5\%D1\%82\%D0\%B8\%D0\%BF+\%D1\%81\%D0\%BE\%D1 \%86\%D1\%96\%D0\%B0\%D0\%BB\%D1\%8C\%D0\%BD\%D0\%BE\%D1\%84\% D1\%96\%D0\%BB\%D0\%BE\%D1\%81\%D0\%BE\%D1\%84\%D1\%81\%D1\%8C \%D0\%BA\%D0\%B8\%D0\%B9+\%D1\%83\%D0\%BA\%D1\%80\%D0\%B0\%D1 \%97\%D0\%BD\%D1\%81\%D1\%8C\%D0\%BA\%D0\%B8\%D0\%B9+\&btnG=( Application date 23.07.2020).

Receptio. Retrieved from http://enc.com.ua/medicina/rezi-riz/25888recepciya.html

DSpace at library NPU Dragomanova. Retrieved from http://enpuir.npu.edu. ua/simple-search (Application date 23.07.2020). 


\title{
Alla Makarova
}

Candidate of Philosophical Sciences (Ph.D.), Doctoral Student of the Department of Philosophy and Political Science, Zhytomyr State Ivan Franko University; Zhytomyr, Ukraine;e-mail: Makarova_AO@ukr.net; ORCID: https://orcid.org/0000-0001-7270-0135

\section{The phenomenon of archetype in contemporary ukrainan sociophilosophical receptions}

\begin{abstract}
Contemporary ukranian philosophical science is in the process of finding new ways to justify their own senses and objectives in the context of realies and perspectives of the social complexity. In articles, they argument the presence of sociophilosophical receptions in contemporary ukranian philosophical studies of archetype phenomenon as a metodological tool of solving these objectives. The goal of the study is proving relevance and perspectivity of appeal in contemporary ukranian sociophilosophical discourse to phenomenon of archetype as such, which matches the specific of discource, it's theoretical, metodolical and practical principles. Objective of the work is analysis of the relevant state of the contemporary ukranian study of the archetype; justification of the presence of receptions of sociophilosophical discource in differently specialized contemorary ukranian studies given the crossdisciplinarity and cross-border issues of the archetype; outlining perspectives of using the archetypal approach as the part of metodological discource in ukranian sociophilosophical receptions of the future. Realizing these objectives makes up the novelty of the research, which has review and analyical nature. The deployment of metodological process of defining the roles of the phenomenon of archetype in ukrainian sociophilosophical paradigm was illustrated; proven the correlation between sociophilosophical studies of the phenomenon of archetype (in the context of it's connection with different sociohumanitary phenomena) and principles of social analysis in the future. Conclusion was made, that: 1) Definition of "archetype" is a base of the scientific discourse, which contributes to the development of sociohumanitary knowledge in general; 2) In crossdisciplinary studies of the phenomenon of archetype the metods of sociophilosophical analysis were used, which makes it possible for interpretation dialog and creation of practical correalitive models of social being; 3) At the level of sociophilosophical analysis of global social clusters, the archetype component in con-
\end{abstract}


temporary ukranian sociophilosophical studies stands out as system-forming; 4) An important metodological meaning archetypal approach gains in the area of influence of the ukranian society creation. Archetypal-axiological approach is defined as such, that is promising in the process of searching of new approaches in sociophilosophical discourse in solving relevant objectives of philosophy.

Keywords: archetype, contemporary ukrainian philosophy, sociophilosophical receptions, sociophilosophical discours, archetypal approach. 